\title{
STUDI KASUS PATOLOGI GIGI: KARIES PADA RANGKA MANUSIA ST1, SONG TERUS, PACITAN, JAWA TIMUR \\ ( Dental Pathology Case Study: Caries On ST1 Human Remains, Song Terus, Pacitan, East Java)
}

\author{
Anita Tamu Ina ${ }^{1 *}$, Dyah Prastiningtyas ${ }^{2}$, Harry Widianto ${ }^{3}$, Florent Détroit ${ }^{4}$, Ferry Fredy Karwur ${ }^{5}$, \\ Andri Purnomo ${ }^{6}$, Anne-Marie Sémah ${ }^{7}$, dan François Sémah ${ }^{4}$ \\ ${ }^{1}$ Program Studi Magister Biologi, Universitas Kristen Satya Wacana, Salatiga \\ ${ }^{2}$ Center for Prehistory and Austronesian Studies, Jakarta \\ ${ }^{3}$ Pusat Penelitian Arkeologi Nasional, Jakarta \\ ${ }^{4}$ Département de Préhistoire, Muséum national d'Histoire naturelle, Paris, France \\ ${ }^{5}$ Fakultas Kedokteran dan Ilmu Kesehatan, Universitas Kristen Satya Wacana, Salatiga \\ ${ }^{6}$ Program Studi Magister Studi Pembangunan dan Interdisiplin, Universitas Kristen Satya Wacana, \\ Salatiga \\ ${ }^{7}$ Institut de Recherce Pour le Developpement, France \\ e-mail: anitamuina@yahoo.com
}

\section{INFO ARTIKEL}

Keywords

Caries,

Dental pathology,

Song Terus,

Early Holocene,

East Java

\section{Kata Kunci \\ Caries, \\ Patologi gigi, \\ Song Terus, \\ Holosen Awal, \\ Jawa Timur}

\section{ABSTRACT}

Human remains found in Song Terus (Pacitan, East Java), known as ST1, presented an opportunity of in-depth study in reconstructing how human lived during Early Holocene period in the area. This article focuses on palaeopathological aspects by examining lesions of disease observable in bones and dentition of human remains found in archaeological context. The research done for this article focuses more on dental remains, as teeth are known to have durability and longevity as archaeological finds, and could also provide information on age-at-death, types of diet, and oral diseases which may occurred during a person's life. Dental caries is one of the most common type of oral disease found in archaeological context. Research methods used are macroscopic observation and literature reference comparison.. Results showed there were nine dentition on this individual (from a total of 27 identified dentition) suffered from caries with various degree of severity. Other types of oral disease noted during observation and analysis were periodontal disease. ST1 might have been suffering from severe caries due to lack of oral hygiene, as well as minimum dental treatment towards emerging oral disease. Nevertheless, these diseases did not seem to be directly caused by STI's dietary habit during lifetime.

\section{ABSTRAK}

Temuan rangka manusia ST1 di Song Terus (Pacitan, Jawa Timur) memberikan peluang untuk menelusuri lebih jauh pola kehidupan manusia pada periode Holosen Awal di wilayah ini. Artikel ini berfokus pada aspek paleopatologi yang merupakan salah satu kajian ilmu dalam menelusuri jejak kehidupan manusia di masa lalu melalui penyakit pada tulang dan gigi manusia yang ditemukan dalam konteks arkeologi. Materi penelitian dalam artikel ini menitikberatkan pada gigi manusia yang merekam informasi mengenai masa hidup seseorang, termasuk aspek-aspek perkiraan usia saat mati, jenis makanan yang pernah dikonsumsi, dan penyakit yang pernah diderita. Kasus patologi berupa karies menarik untuk diteliti sebab penyakit ini merupakan salah satu kasus yang umum ditemukan pada sisa rangka manusia. Metode penelitian yang digunakan adalah observasi makroskopis dan metode pustaka. Hasil analisis menunjukkan bahwa dari 27 gigi tersisa pada individu ST1, terdapat sembilan gigi yang terdeteksi mengalami karies dan beberapa gigi lain yang menderita penyakit periodontal. Karies pada individu ini tampak disebabkan oleh mikro-organisme yang berkembang di dalam mulut akibat minimalnya perawatan kesehatan gigi dan mulut, serta tidak berhubungan langsung dengan asupan nutrisi yang dikonsumsi oleh individu ini pada masa hidupnya. 


\section{PENDAHULUAN}

Kawasan Gunung Sewu terletak di sepanjang pantai selatan Jawa yang membentang sekitar $85 \mathrm{~km}$ antara Teluk Pacitan (di bagian timur) dan Sungai Oyo (di bagian barat) yang merupakan perbukitan karst dengan banyak gua dan ceruk alam yang dianggap ideal sebagai hunian manusia prasejarah. Di dalam kawasan karst Gunung Sewu setidaknya terdapat sekitar 135 situs prasejarah yang telah diidentifikasi dan jumlahnya masih diperkirakan terus bertambah seiring dengan adanya informasi situs baru (Simanjuntak, 2004:9). Potensi arkelogis di wilayah ini menjadikan Gunung Sewu sebagai salah satu fokus penelitian bagi ahli-ahli arkeologi dalam dan luar negeri, seperti Pusat Penelitian Arkeologi Nasional, Museum national d'Histoire Naturelle (Paris), dan sebagainya. Penelitian-penelitian yang dilaksanakan di wilayah Gunung Sewu berusaha untuk menelusuri jejak-jejak penghunian awal oleh manusia di kawasan karst Gunung Sewu yang diperkirakan berlangsung sekitar Plestosen Akhir Holosen Awal.

Budaya tertua di wilayah ini ditandai dengan adanya kehidupan dan pemanfaatan lahan terpusat di bentang alam terbuka, yaitu di sekitar dan sepanjang aliran sungai. Saat berkembangnya tahap kehidupan dari masa Plestosen ke Holosen, terjadi perubahan model hunian yang ditandai dengan peralihan ke hunian gua dan ceruk. Situs-situs prasejarah di Gunung Sewu menjadi bukti kedatangan awal Homo sapiens di Asia Tenggara, khususnya di Indonesia. Hal ini didukung dengan sejumlah temuan sisa manusia, seperti yang ditemukan di Gua Braholo, Song Keplek, dan Song Terus. Individu-individu ditemukan di Gua Braholo (di bagian barat Gunung Sewu) memiliki hasil pertanggalan yang berkisar antara 13.000-9.000 tahun yang lalu. Sementara di

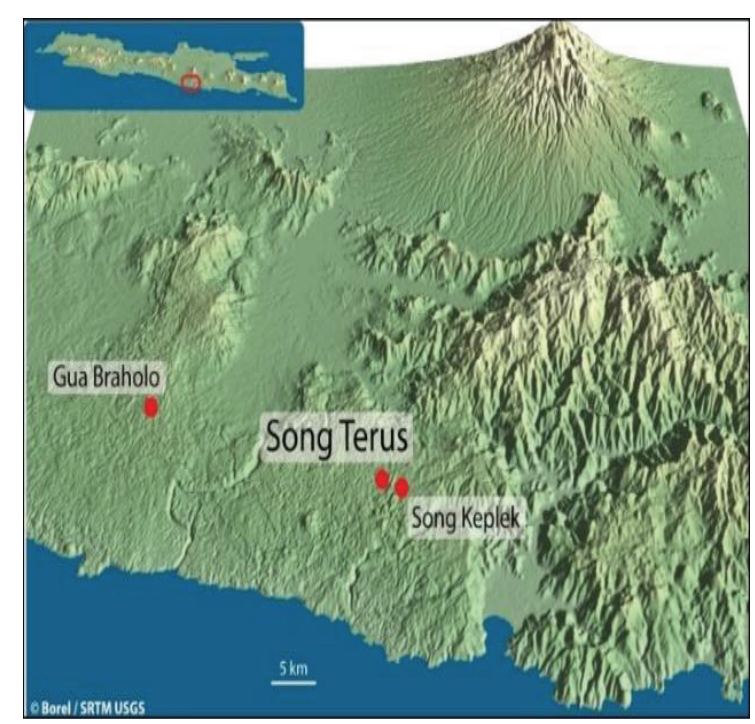

Gambar 1. Peta Lokasi Song Terus

bagian timur Gunung Sewu, temuan sisa manusia ditemukan di bagian timur gunung Sewu, temuan sisa manusia ditemukan di Song Terus (Gambar 1) dan Song Keplek dengan pertanggalan yang berkisar 10.000$7.000 \mathrm{BP}$. 


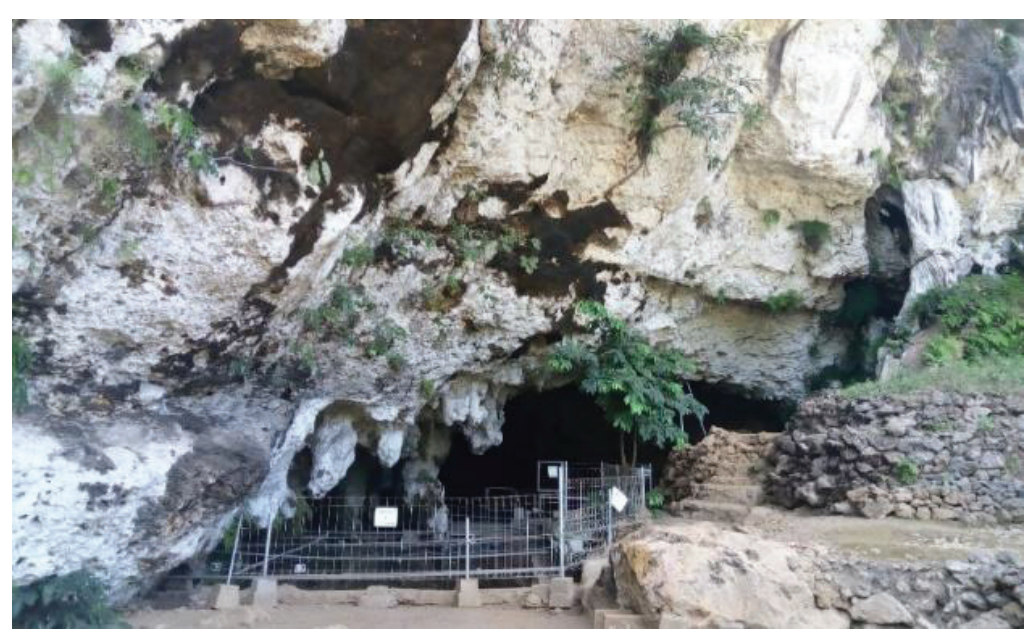

Gambar 2. Song Terus Tampak Depan

Berdasarkan karakter morfologi dari sisa lapisan arkeologis, yaitu Lapisan Terus, rangka manusia, individu-individu yang Lapisan Tabuhan, dan Lapisan Keplek ditemukan di wilayah ini diduga berkaitan dengan rentang waktu sekitar 230.000 erat dengan keberadaan populasi ras 5.000 tahun yang lalu (Semah, dkk, 2004:56; Australomelanesid di zaman Akhir Plestosen Hameau, dkk, 2007:399; Detroit, 2002:211). - Awal Holosen yang bukan merupakan Penelitian ini lebih difokuskan pada temuan penduduk masa kini (Widianto, 2002:230). sisa manusia paling utuh yang ditemukan dari Australomelanesid merupakan salah satu Lapisan Keplek di Song Terus yang populasi ras manusia modern yang ada di diberikan nomor katalog ST1. Lapisan ini Indonesia yang diperkirakan datang dan mempunyai kisaran rentang waktu antara menetap lebih dulu dibandingkan dengan ras 10.000 - 5.000 tahun yang lalu yang sangat Mongoloid. kaya dengan alat-alat batu, alat-alat tulang,

Song Terus yang terletak di Punung, sisa-sisa fauna, dan sisa rangka manusia. Pacitan (Jawa Timur) merupakan salah satu Temuan-temuan ini antara lain berupa situs prasejarah penting di Asia Tenggara fragmen tengkorak lepas (parietal kiri), dengan sejarah stratigrafi yang panjang, fragmen tengkorak kanan, dua buah tulang dimulai dari masa Plestosen Tengah sampai jari, dan beberapa gigi lepas (Detroit, Holosen Awal (Gambar 2). Penelitian- 2002:215). Temuan-temuan sisa manusia ini penelitian yang sudah dilakukan di situs ini menarik untuk ditelaah sebab mereka berhasil mengungkap bahwa terdapat tiga menyimpan banyak informasi mengenai 
kehidupan masa lalu di wilayah Gunung Sewu.

\section{Profil Individu ST1}

Individu ST1 adalah sisa manusia yang ditemukan pada tahun 1999 di Situs Song Terus (Détroit, 2002:215). Individu ini ditemukan di dinding utara gua dan dikuburkan dalam posisi terlipat dengan posisi tubuh sedikit miring menindih sisi kanannya. Secara anatomis, individu ini ditemukan cukup utuh dan masing-masing tulangnya masih berada dalam artikulasi yang sesuai dengan anatomi tubuh manusia (Gambar 3). Hal ini menunjukkan bahwa individu ini dikuburkan secara primer dan langsung tanpa wadah. Tengkorak individu ini tidak ditemukan dalam keadaan utuh sebab telah rusak dan hancur oleh erosi alami yang terjadi di sepanjang dinding gua. Pecahan fragmen proksimal epifisis dan skapula kiri ditemukan di dekat dinding gua. Humerus kiri tergeletak di dinding gua. Bagian lengan bawah kiri ditemukan dalam posisi tegak lurus terhadap humerus kiri yang terletak di antara lutut. Lengan kanan individu ini ditemukan melipat di sisi tubuh dan tangan kanan ditemukan hampir per menyentuh bagian wajahnya. Kedua kaki elemen tulang/gigi dari ST1. vertebrae yang menunjukkan posisi hiperfleksi (tertekuk penuh). Tulang lutut ditemukan di bawah sternum dan terletak beberapa sentimeter di depan kolom vertebralis. Tarsal dan metatarsal menunjukkan bahwa individu memiliki tulang kaki yang panjang dan terjepit di antara dinding gua dan sebuah blok batu kapur. Tulang-tulang kaki yang ditemukan pada individu ini memperlihatkan adanya patahan-patahan tulang yang terjadi setelah individu meninggal (postmortem). Analisis awal yang berkaitan dengan jenis kelamin dan usia mati individu ini menunjukkan bahwa ST1 adalah seorang laki-laki yang berusia sekitar 45-55 tahun (Détroit, 2002:229). Beberapa jejak patologi dapat dengan jelas direkam pada tulang-tulang individu ini, seperti patah tulang pada ulna dan femur. Pertanggalan $\mathrm{C}_{14}$ atas rangka ini diambil dari sampel cangkang moluska yang terletak berdekatan dengan rangka dan menunjukkan angka 9.330+90 tahun yang lalu (Détroit, 2002:215; Widianto, dkk, 2010:116). Sampai saat ini belum ada penelitian lanjut atau publikasi terbaru terkait pertanggalan yang langsung menggunakan 
Penelitian lanjutan terkait individu ST1 yang ditemukan juga dilakukan oleh Perelli (2010) dan Noerwidi (2012). Perelli menganalisis individu tersebut berdasarkan morfometri tulang panjang individu ST1 dan menyimpulkan bahwa individu ini termasuk dalam ras Australomelanesid. Setelah itu, Noerwidi juga melakukan perbandingan morfologi ST1 dengan individu lainnya yang ditemukan di beberapa situs di wilayah Gunung Sewu seperti Song Keplek, Gua Braholo, dan bahkan Gua Pawon (Jawa Barat), dan hasilnya individu Song Terus menunjukkan ciri ras Australomenesid.

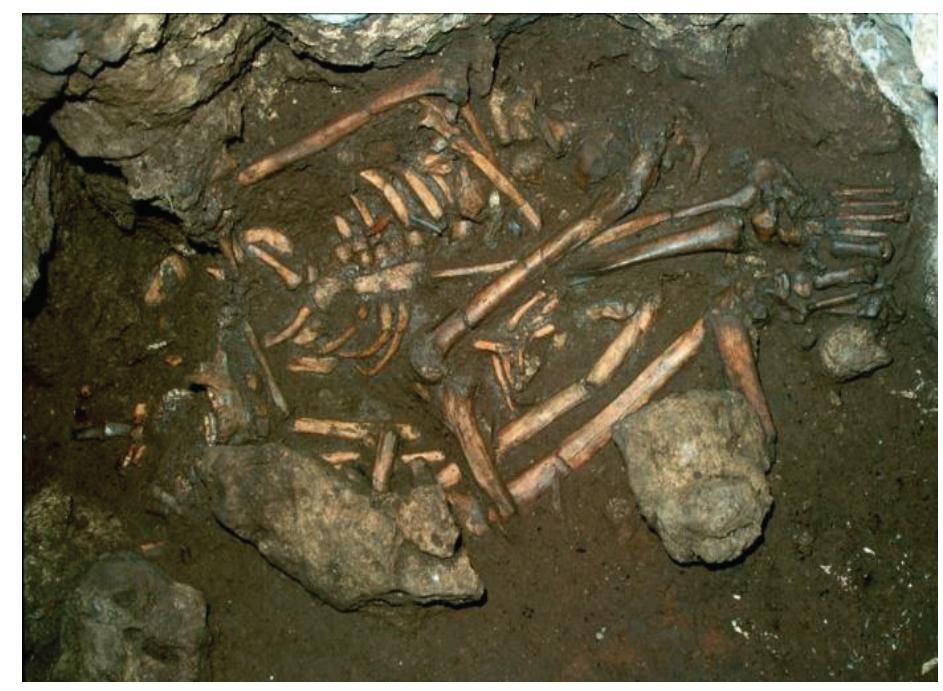

Gambar 3.Foto Fitur Kubur ST1 di Song Terus (sumber : Detroit, 2002)

\section{Permasalahan dan Tujuan Penelitian}

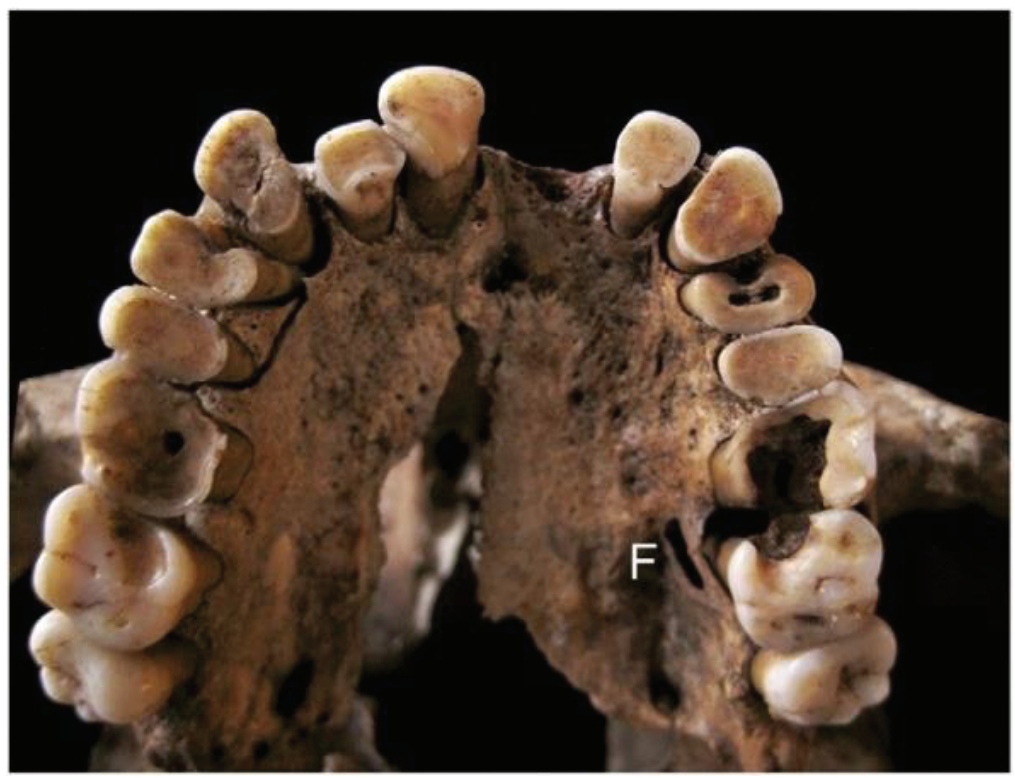

Gambar 4. Patologi Gigi pada sisa rangka manusia.

Salah satu aspek yang menarik untuk patologi yang dapat diamati pada tulang diteliti dari sisa manusia ST1 adalah jejak ataupun giginya. Jejak-jejak patologi 
berhubungan dengan kondisi kesehatan dan juga dapat menunjukkan adanya perilakuperilaku budaya yang pernah dijalani seseorang. Gigi adalah bagian tubuh manusia yang paling sering bersentuhan dengan lingkungan luar. Namun, gigi juga merupakan bagian yang paling keras dalam tubuh manusia maka ketika melakukan pengamatan / penelitian, resiko kerusakan bagian gigi yang diteliti sangat kecil bila dibandingkan dengan tulang manusia yang mudah rapuh. Gigi manusia merekam banyak informasi mengenai masa hidup individu yang mencakup aspek-aspek perkiraan usia saat mati, jenis makanan yang pernah dikonsumsi, keadaan lingkungan sekitar tempat tinggalnya, perilaku budaya, aktivitas yang mungkin dilakukan, dan penyakit yang pernah diderita (Hillson, 2005:1; Hublin, dkk, 2007:291). Salah satu kasus patologi gigi yang paling sering ditemukan dalam konteks arkeologis adalah karies. Lesi karies dengan adanya lubang pada dentin gigi yang disebabkan oleh mikroorganisme. Bila seseorang menderita karies yang sudah sangat akut, maka akan terbentuk abses (lubang pada dinding alveolar) dan penanggalan gigi. Dari beberapa penelitian paleopatologi yang pernah dilakukan pada temuan gigi seperti temuan karies pada sisa rangka manusia yang ditemukan di Maroko, Jepang, Italia, Filipina, dan juga Indonesia
(Gua Harimau, Sumatera Selatan dan Liang Bua, Flores) hampir setiap gigi individu yang ditemukan memiliki karies (Gambar 4) (Arizona, 2016:260; Larsen, dkk, 1991:184). Gigi-gigi yang ditemukan pada ST1 memperlihatkan kondisi yang cukup baik dan dinilai layak sebagai bahan penelitian yang difokuskan pada pengamatan dan kajian pada patologi gigi (Gambar 5). Secara umum, hampir semua gigi ST1 ini menunjukkan adanya atrisi pada bagian oklusal giginya dan terdapat beberapa gigi yang mengalami karies. Penelitian yang fokusnya untuk mengenali profil karies pada gigi-gigi ST1 ini diharapkan dapat memberikan ilustrasi mengenai kehidupan individu ST1 di masa lalu, termasuk mengetahui penyebab karies gigi, pola diet, dan juga profil kesehatan oral individu ST1.

\section{Metode dan Materi Penelitian}

Metode yang digunakan dalam penelitian ini adalah metode pustaka dan observasi makroskopis yaitu pengamatan non-metrik pada gigi maksila dan mandibula ST1. Observasi makroskopis meliputi identifikasi dan katalogisasi gigi tersisa pada individu ini. Langkah berikutnya adalah melakukan pengamatan, pencatatan, dan identifikasi lesi-lesi patologis pada gigi-gigi tersebut. Metode pustaka dilakukan setelah observasi makroskopis untuk 

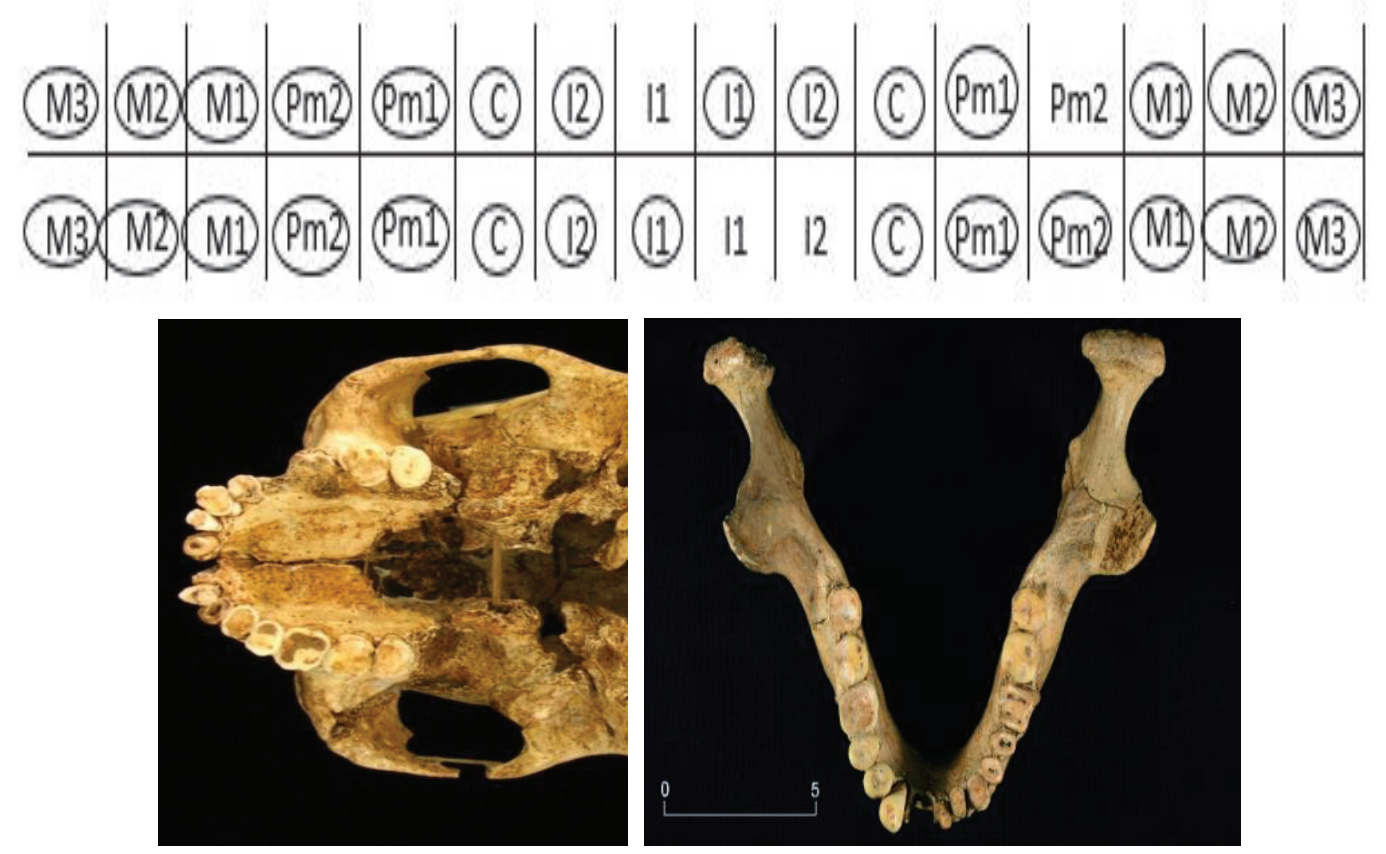

Gambar 5 dan 6. Gigi Maksila dan Mandibula ST1 (tampak oklusal)

menganalisis dan membandingkan hasil demikian, terdapat pula beberapa gigi yang observasi makroskopis dengan sumber- sudah tidak dapat ditemukan.

sumber literatur yang berkaitan dengan patologi gigi yang teridentifikasi, dalam hal ini adalah karies.

Objek penelitian ini menggunakan gigi - gigi pada maksila dan mandibula ST1 yang ditemukan dalam kondisi cukup utuh saat ekskavasi. Maksila ST1 ini ditemukan masih berartikulasi dengan tengkoraknya, meskipun terfragmentasi pada bagian premaxillary suture-nya. Mandibula individu ini juga ditemukan dalam kondisi lengkap, meskipun ditemukan dalam keadaan terfragmentasi. Fragmen-fragmen mandibula masih dapat direkonstruksi sesuai dengan bentuk anatomisnya kembali. Hampir seluruh gigi geligi individu ST1 ditemukan masih melekat pada alveolarnya. Meskipun
Gigi yang berhasil ditemukan pada individu ST1 berjumlah 28 buah gigi dan 4 gigi lainnya tidak ditemukan saat ekskavasi, baik pada mandibula maupun maksilanya. Identifikasi dan deskripsi gigi tersisa mengacu pada istilah-istilah yang sesuai dengan posisi anatomis gigi pada mulut manusia. Kode-kode gigi yang berada di atas garis skema merupakan kode gigi maksila ditunjukkan dengan superscript sedangkan yang di bawahnya merupakan kode gigi mandibula ditunjukkan dengan subscript ( $\quad$ (x). Untuk memudahkan pengidentifikasian gigi berdasarkan sisi lokasi di dalam mulut, maka digunakan kode $\mathrm{R}$ (right) untuk gigi yang terletak di sebelah kanan, dan kode L (left) untuk gigi yang terletak di sebelah kiri. Untuk pendeskripsian 
jenis gigi digunakan istilah incisor (I) untuk Tiga gigi lainnya yaitu $\mathrm{LI}^{1}, \mathrm{RI}_{1}$, dan $\mathrm{RI}_{2}$ gigi seri, canine (C) untuk gigi taring, pre- sudah tidak ditemukan saat ekskavasi. molar (Pm) untuk gigi geraham kecil, dan Hilangnya ketiga gigi tersebut diperkirakan molar (M) untuk gigi geraham besar. terjadi ketika individu masih hidup Berdasarkan kode deskripsi dan identifikasi (antemortem), terlihat dari adanya penutupan gigi-gigi tersebut, maka dalam menyebutkan alveolar pada $\mathrm{LI}^{1}$, $\mathrm{RI}_{1}$, dan $\mathrm{RI}_{2}$. Gigi $\mathrm{RI}^{1}$ gigi seri pertama pada maksila sebelah kiri masih melekat pada alveolarnya dan akan dituliskan $\mathrm{LI}^{1}$ sedangkan untuk gigi seri memiliki lubang di bagian dentin yang dapat pertama pada mandibula akan dituliskan $\mathrm{LI}_{1}$, diidentifikasikan sebagai karies. $\mathrm{RI}^{1}$ memiliki dan berlaku untuk gigi selanjutnya. bentuk mahkota (crown) giginya yang bulat,

Identifikasi gigi tersisa pada ST1 tidak pipih seperti gigi seri pada umumnya menunjukkan bahwa maksila memiliki 14 (White, dkk, 2005:134). Selain itu mahkota gigi tersisa, yaitu $\mathrm{RI}^{1}, \mathrm{RI}^{2}, \mathrm{LI}^{2}, \mathrm{RC}, \mathrm{LC}$, giginya pun lebih pendek dibandingkan gigi $\mathrm{RPm}^{1}, \mathrm{LPm}^{1}, \mathrm{LPm}^{2}, \mathrm{RM}^{1}, \mathrm{RM}^{2}, \mathrm{RM}^{3}, \mathrm{LM}^{1}$, yang lain yang mungkin disebabkan oleh $\mathrm{LM}^{2}$, dan $\mathrm{LM}^{3}$. Sementara itu, mandibula hilangnya enamel gigi akibat karies yang ST1 memiliki 14 gigi tersisa yaitu $\mathrm{LI}_{1}, \mathrm{LI}_{2}$, sudah parah. Secara umum, RI ${ }^{1}$ ini telah $\mathrm{LC}, \mathrm{RC}, \mathrm{RPm} 1, \mathrm{RPm} 2, \mathrm{LPm}_{1}, \mathrm{LPm}_{2}, \mathrm{RM}_{1}$, mengalami resorpsi yang menyebabkan $\mathrm{RM}_{2}, \mathrm{RM}_{3}, \mathrm{LM}_{1}, \mathrm{LM}_{2}$, dan $\mathrm{LM}_{3}$ (Gambar 6). bagian alveolarnya rusak sehingga akar

\section{Patologi Gigi ST1} giginya dapat terlihat dan mengandung kalkulus pada seluruh bagian giginya. $\mathrm{RI}^{2}$ Gigi seri yang ditemukan pada menunjukkan atrisi gigi pada mahkotanya individu ST1 berjumlah lima yaitu tiga gigi dan mengandung kalkulus pada akar giginya. pada maksila dan dua gigi pada mandibula Tidak terindikasi karies tetapi mengalami yang terdiri atas $\mathrm{RI}^{1}, \mathrm{RI}^{2}, \mathrm{Ll}^{2}, \mathrm{LI}_{1}$, dan $\mathrm{LI}_{2}$. resorpsi sehingga menyebabkan hilangnya
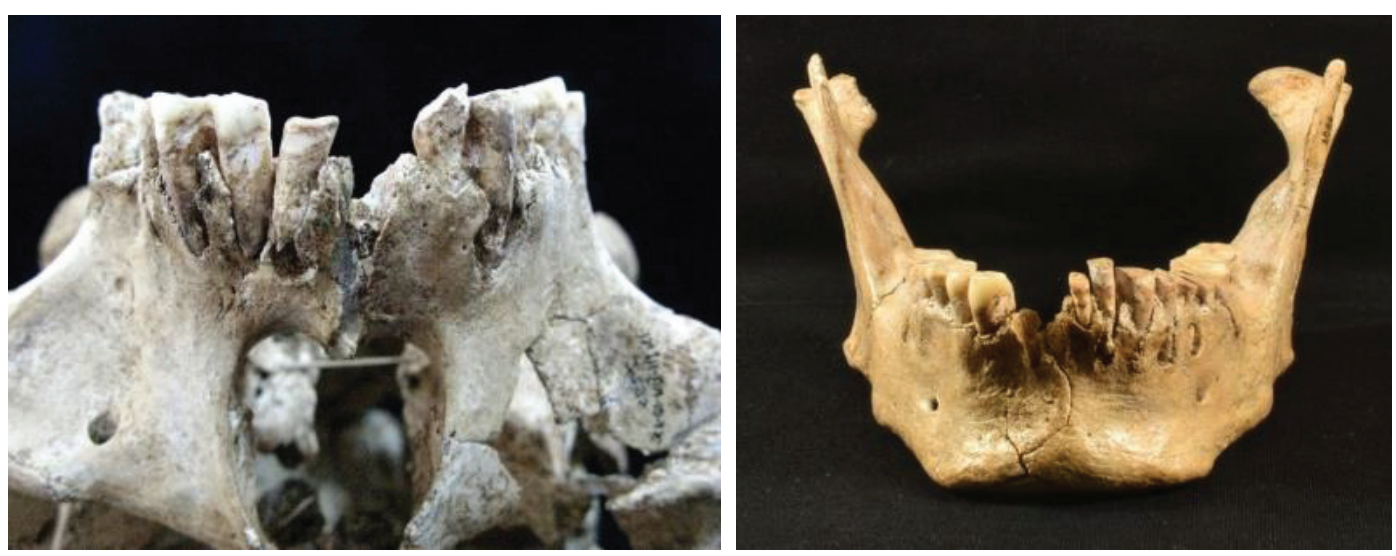

Gambar 7. Karies incisor dan canine 
dinding sekat alveolar antara $\mathrm{RI}^{2}$ dan $\mathrm{RI}^{1}$. $\mathrm{LI}^{2}$ ditemukan masih melekat pada alveolarnya dan terdapat patahan (chipping) pada bagian mahkota dan leher giginya. Patahan pada leher gigi mungkin disebabkan oleh gesekan saat post-mortem karena pada mahkota gigi terlihat bekas patahan berwarna putih yang mengindikasikan patahan terjadi setelah individu meninggal. Selain itu, pada patahan mahkota tersebut juga ditemukan lubang pada dentin yang menunjukkan adanya

karies gigi. Gigi ini akar giginya mengalami resesi dan kalkulus pada bagian akarnya. Pada bagian mandibulanya, gigi $\mathrm{LI}_{1}$ menunjukkan adanya karies yang ditandai dengan adanya lubang kecil di tengah dentin berukuran sekitar $0,13 \mathrm{~mm}$ dan abses pada tulang alveolarnya sekitar $3 \mathrm{~mm}$. Pada $\mathrm{LI}_{2}$ mengalami resesi pada tulang alveolarnya dan juga abses, namun tidak menunjukkan adanya karies (Gambar 7).

ST1 memiliki empat gigi taring yang masih lengkap. LC pada mandibula masih melekat pada alveolar dan mahkota giginya di bagian labial terdapat patahan dan tidak terindikasi adanya jejak karies. Pada RC, gigi ST1 ini mengalami atrisi pada bagian dentinnya dan tidak ditemukan indikasi adanya karies. Pada maksila LC ditemukan adanya karies gigi pada dentin yang berlubang dengan kedalaman sekitar 0,2 $\mathrm{mm}$. Gigi ini juga mengalami resorpsi dan banyak memiliki banyak kalkulus di hampir seluruh bagian giginya. Berbeda dengan LC, pada
RC tidak menunjukkan adanya karies tetapi adanya atrisi gigi pada dentin giginya dan akar giginya mengalami resorpsi dan mengandung banyak kalkulus.

Gigi yang diidentifikasi sebagai gigigigi geraham kecil pada ST1 berjumlah tujuh yang terdiri dari tiga gigi maksila yaitu $\mathrm{LPm}^{1}, \mathrm{RPm}^{1}, \mathrm{LPm}^{2}$, dan empat gigi mandibula yaitu $\mathrm{RPm}_{1}, \mathrm{LPm}_{1}, \mathrm{LPm}_{2}, \mathrm{RPm}$. $\mathrm{RPm}^{2}$ sudah tidak ditemukan lagi dan alveolarnya sudah menutup. Gigi $\mathrm{RPm}^{1}$ menunjukkan ada patahan gigi bagian lingual sehingga bagian pulpanya terlihat (seperti teriris) dan mengalami resorpsi. $\mathrm{LPm}^{1}$ menunjukkan adanya atrisi gigi pada bagian dentinnya. Hampir sama seperti gigi-gigi lainnya, gigi ini juga mengalami resesi dinding alveolar dan terdapat patahan pada bagian buccal dan akar giginya mengandung kalkulus. Dari observasi enamelnya, gigi ini tidak mengandung karies. Gigi ini juga mengalami atrisi gigi sehingga hampir sebagian enamelnya terekspos. Perbedaan lebar mahkota yang cukup signifikan antara $\mathrm{LPm}^{1}$ dan $\mathrm{RPm}^{1}$ (sekitar 1,97 mm) menunjukkan bahwa gigi ini mengalami kerusakan yang cukup besar akibat karies dan atrisi. Gigi $\mathrm{LPm}^{2}$ menunjukkan adanya patahan pada bagian buccal giginya dan adanya atrisi gigi, namun tidak terindikasi karies. Bagian leher gigi sampai akar gigi mengandung banyak kalkulus. Pada RPm 1 , akar giginya masih melekat pada alveolar dan tidak mengandung karies. Bagian mahkota 

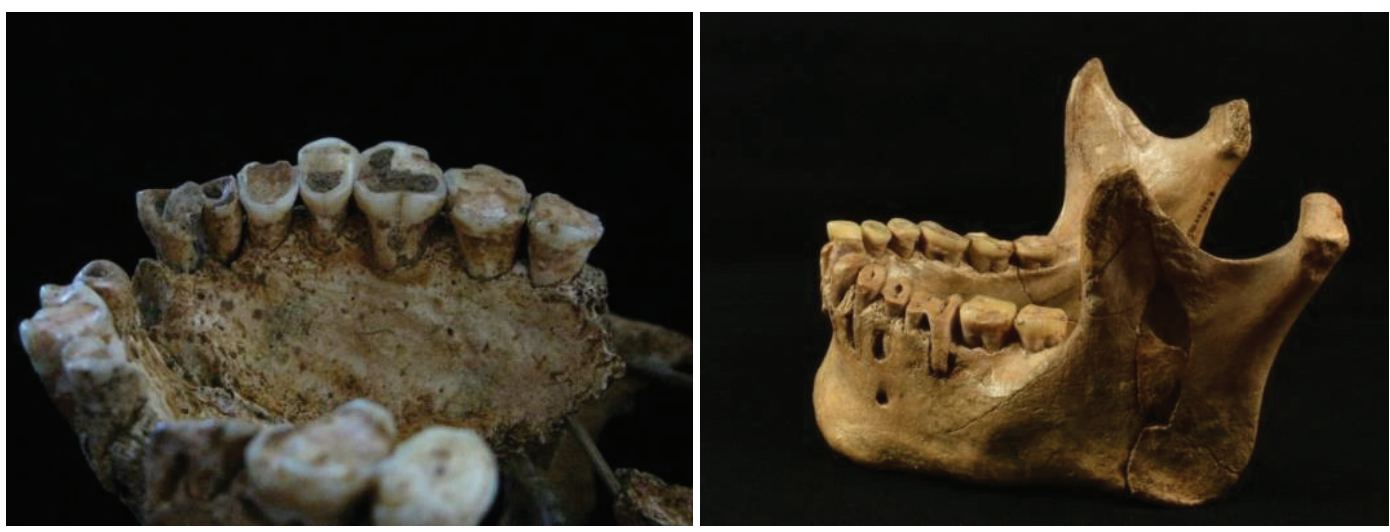

Gambar 8. Karies gigi premolar dan molar

giginya memiliki patahan pada bagian labialnya dan menunjukkan gejala atrisi pada bagian oklusal. LPm 1 mengandung karies gigi yang ditandai dengan adanya lubang sekitar 0,08 $\mathrm{mm}$ pada bagian dentinnya. Gigi $\mathrm{LPm}_{2}$ memiliki karies pada dentin mahkota giginya. Bagian akar giginya terlihat pada sekat alveolar karena adanya abses pada tulang alveolarnya. Gigi $\mathrm{RPm}_{2}$ hanya menunjukkan adanya atrisi pada mahkota giginya dan akar giginya masih melekat pada alveolar.

Gigi geraham ST1 berjumlah dua belas gigi yang terdiri dari enam gigi maksila yaitu $\mathrm{LM}^{1}, \mathrm{LM}^{2}, \mathrm{LM}^{3}, \mathrm{RM}^{1}, \mathrm{RM}^{2}$, dan $\mathrm{RM}^{3}$, dan enam gigi mandibula yaitu $\mathrm{LM}_{1}, \mathrm{LM}_{2}$,

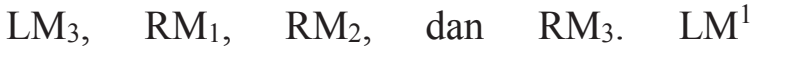
menunjukkan adanya atrisi di hampir seluruh dentin mahkota giginya. Ada patahan juga di bagian pinggiran enamelnya. Akar giginya mengandung kalkulus dan tidak ada karies. $\mathrm{RM}^{1}$ terindikasi karies yang parah karena hampir sebagian besar mahkotanya terekspos habis. Bila dilihat dari lebar mahkota giginya, 0,1 mm di bagian lingual crown. Bagian akar $\mathrm{RM}^{1}$ ini memiliki ukuran terkecil giginya masih melekat pada dinding alveolar 
namun mengalami resesi. Sama seperti $\mathrm{RM}_{1}$, $\mathrm{LM}_{1}$ juga mengalami patahan pada lingual crown, resesi alveolar, dan adanya karies disertai atrisi pada bagian dentinnya. $\mathrm{LM}_{2}$, $\mathrm{RM}_{2}, \mathrm{RM}_{3}$, dan $\mathrm{LM}_{3}$ sama-sama mengalami patahan dan atrisi pada mahkota giginya. Keempatnya memiliki atrisi yang cukup parah yang terlihat pada seluruh bagian dentin mahkota giginya (Gambar 8).

\section{PEMBAHASAN}

Karies gigi adalah salah satu patologi gigi yang sangat signifikan ditemukan pada individu ST1. Penyakit ini terjadi karena demineralisasi email dan dentin oleh asam organik yang terbentuk oleh bakteri pada plak gigi yang berasal dari makanan yang mengandung gula (Tampubolon, 2005:3; Moynihan, 2005:695). Makanan merupakan salah satu faktor utama penyebab karies gigi selain mikroorganisme, gigi dan waktu. Pembentukan karies gigi disebabkan oleh asam yang dihasilkan oleh aksi mikroorganisme terhadap karbohidrat. Reaksi ini ditandai dengan dekalsifikasi komponen inorganik dilanjutkan oleh disintegrasi substansi organik yang berasal dari gigi. Hal ini menyebabkan demineralisasi email berlanjut menjadi karies gigi dimulai dari permukaan gigi (pits, fissure, dan daerah interproksimal) meluas ke arah dentin sampai pulpa (Ramayanti, 2013:89).

Kemunculan patologi gigi seperti karies tidak terlepas dari beberapa faktor seperti keadaan geografis, kemampuan beradaptasi, pola diet, pola mengunyah, serta pola dalam menjaga kesehatan gigi dan mulut. Penelitian yang dilakukan Lubell (dalam Arizona, 2016:260) menunjukkan bahwa pada rangka dan gigi-geligi manusia yang hidup pada masa transisi dari Mesolitik sampai Neolitik menunjukkan jenis patologis seperti tanggalnya gigi dan karies gigi. Ubelakar (1997, dalam Arizona 2016:260) juga melaporkan bahwa rangka manusia yang hidup yang pada tiga periode berbeda (dari masa prasejarah-sejarah) menunjukkan bahwa jenis patologis seperti patologi gigigeligi, peradangan pada tulang, trauma pada tulang, hiperostosis, dan deformasi tengkorak sebagai wujud dampak dari perkembangan lingkungan dan budaya.

Karies gigi dipengaruhi oleh pola diet dan pola mengunyah makanan (Ortner, 2003:439). Selain itu kondisi kesehatan gigi dan mulut yang tidak dijaga akan membuat bakteri di dalam mulut berkembang dengan cepat. Adanya plak yang menempel pada gigi menjadi media yang dapat membantu bakteri menempel dan menyebabkan karies semakin cepat. Apabila dikaitkan dengan pola menguyah makanan maka karies akan tampak pada daerah oklusi (bagian permukaan dentin untuk mengunyah).

Analisis yang dilakukan pada gigi geligi individu ST1 menunjukkan adanya beberapa jejak patologi yang indikasinya dapat dilihat pada maksila dan mandibula 
ST1 yaitu karies gigi, patahan gigi, abses, resorpsi, dan resesi dinding alveolar. Pada ST1, kesembilan gigi yang terkena karies terletak pada bagian tengah dentin giginya dan menyebar ke bagian mahkota dari gigi tersebut. Banyaknya kalkulus pada hampir seluruh bagian gigi ST1 dapat menjadi penyebab terjadinya resesi dan resorbsi akibat penumpukan plak dan bakteri dalam waktu yang lama. Sisa makanan di dalam mulut akan bercampur dengan bakteri sehingga dalam jangka waktu tertentu akan menyebabkan karies dan gangguan periodontal pada individu ST1. Karies pada individu ini berjumlah 9 gigi atau sekitar $32,14 \%$ dari total gigi tersisa dan sisanya mengalami atrisi, patahan, dan penyakit periodontal lainnya seperti abses dan resesi alveolar.

Selain karies, patologi lainnya yang dapat dilihat pada ST1 adalah abses yaitu karies yang menembus pulpa gigi. Hal ini terjadi akibat ruang pulpa gigi mengalami infeksi oleh aktivitas mikroorganisme. Pada hasil pengamatan yang terlihat $\mathrm{LI}_{1}, \mathrm{LI}_{2}, \mathrm{LPm}_{2}$, dan $\mathrm{RM}^{1}$ mengalami abses hingga mencapai ukuran $\pm 3 \mathrm{~mm}$. Ketiga gigi $\left(\mathrm{LI}_{1}, \mathrm{LPm}_{2}\right.$, dan $\mathrm{RM}^{1}$ ) yang mengalami abses tersebut menunjukkan tingkat keparahan karies yang signifikan, sedangkan $\mathrm{LI}_{2}$ tidak mengandung karies namun memiliki abses yang cukup signifikan. Hal ini mungkin dapat terjadi disebabkan oleh mikroorganisme penyebab karies dari gigi yang berada di dekatnya yaitu
$\mathrm{LI}_{1}$, telah membentuk koloni dan menyerang tulang alveolar hingga menyebabkan resorpsi dan abses.

Jejak patologi lain yang diidentifikasi pada individu ST1 adalah periodontal, yaitu tereksposnya tulang alveolar akibat karies yang sudah mencapai akar gigi. Ketiga patologi ini disebabkan oleh aktivitas bakteri di dalam mulut akibat tidak terjaganya kesehatan gigi dan mulut. Atrisi gigi juga banyak ditemukan di hampir setiap gigi ST1. Atrisi gigi ini berkaitan dengan penggunaan gigi yang menyebabkan keausan pada dentin giginya. Semakin tua umur seseorang, maka tingkat keausan giginya semakin tinggi. Kemunculan atrisi yang tinggi dapat mengurangi tingkat karies pada individu karena bagian permukaan gigi yang aus akan sulit untuk ditempeli sisa makanan sehingga bakteri tidak dapat berkembang pada gigi. Namun, dari kesembilan gigi yang terkena karies, ada satu gigi yaitu $\mathrm{RPm}^{1}$ yang juga mengalami atrisi gigi. Karies pada atrisi gigi ini dapat disebabkan oleh penyebaran mikroorganisme dari gigi $\mathrm{RPm}^{2}$ yang kemungkinan tanggal akibat karies dan gigi $\mathrm{RM}^{1}$ yang juga mengalami karies yang cukup parah bila dibandingkan kedelapan gigi lainnya.

Penyakit lainnya adalah periodontal yaitu kondisi dimana tulang alveolar terekspos akibat karies yang sudah mencapai akar gigi. Ketiga patologi ini disebabkan oleh aktivitas bakteri di dalam mulut akibat tidak 
terjaganya kesehatan gigi dan mulut. Atrisi gigi juga banyak ditemukan di hampir setiap gigi ST1. Atrisi gigi ini berkaitan dengan penggunaan gigi yang menyebabkan keausan pada dentin giginya. Semakin tua umur seseorang, maka tingkat keausan giginya semakin tinggi. Kemunculan atrisi yang tinggi dapat mengurangi tingkat karies pada individu karena bagian permukaan gigi yang aus akan sulit untuk ditempeli sisa makanan sehingga bakteri tidak dapat berkembang pada gigi. Namun, dari kesembilan gigi yang terkena karies, ada satu gigi yaitu $\mathrm{RPm}^{1}$ yang juga mengalami atrisi gigi. Karies pada atrisi gigi ini dapat disebabkan oleh penyebaran mikroorganisme dari gigi $\mathrm{RPm}^{2}$ yang kemungkinan tanggal akibat karies dan gigi $\mathrm{RM}^{1}$ yang juga mengalami karies yang cukup parah bila dibandingkan kedelapan gigi lainnya.

ST1 hidup pada kondisi lingkungan hutan hujan tropis dataran rendah yang berdasarkan polen yang ditemukan menunjukkan jenis tumbuhan dari keluarga Podocarpaceae, Dipterocarpaceae, Fagaceae, dan Pteridophyta, sedangkan untuk faunanya sendiri yang ditemukan adalah Elephas sp. dan cercopithecids seperti

\section{Macaca fascicularis dan Trachypithecus} auratus (Amano, dkk, 2016:157). Pada kondisi lingkungan seperti ini kebanyakan tumbuhan yang hidup pada saat itu hanyalah berupa tumbuhan berkayu dan belum ada bukti akurat yang mengatakan bahwa populasi yang hidup di zaman itu mengonsumsi makanan dari empat famili tumbuh-tumbuhan tersebut. Selain itu, karena pada masa tersebut juga budaya agrikultur belum masuk ke Indonesia, maka kemungkinan besar penyebab karies pada individu tersebut adalah masalah kesehatan gigi dan mulut. Makanan yang dikonsumsi ST1 mungkin dapat berasal dari dedaunan tumbuhan, hasil buruan, dan juga kerangkerangan yang terdapat di sekitar Song Terus. Hal ini terbukti dari ditemukannya kerang di dekat rangka ST1. Kerang dan hasil buruan banyak mengandung protein dibandingkan karbohidrat yang merupakan salah satu penyebab adanya karies. Namun demikian, zat apapun yang dikonsumsi manusia akan mempercepat terjadinya karies apabila kondisi kesehatan gigi dan mulut tidak diperhatikan. Hal ini akan menyebabkan mikroorganisme penyebab karies dapat berkembang dengan baik di dalam mulut sehingga akan merusak struktur gigi secara umum. Tidak adanya usaha untuk melakukan perawatan pada gigi-gigi yang terkena karies akan menyebabkan penyakit tersebut terus berkembang menjadi semakin parah.

\section{PENUTUP}

Patologi gigi merupakan bagian dari masalah kesehatan yang muncul akibat berkembangnya pola kehidupan manusia. Rangka individu ST1 yang ditemukan di 
Song Terus memiliki banyak aspek patologis yang menarik diteliti seperti patologi karies pada gigi yang tersisa. Karies pada ST1 terdapat pada setiap jenis gigi baik pada maksila maupun mandibula. Kesembilan gigi yang mengandung karies terletak pada bagian tengah dentin gigi. Karies yang paling parah ditandai dengan adanya abses yang melubangi tulang alveolar pada gigi ST1. Masalah kesehatan mulut dan gigi menjadi penyebab utama terjadinya karies pada ST1. Sisa makanan yang tertinggal di gigi menjadi media tumbuh bagi mikroorganisme mulut yang berkembang dengan baik sehingga merusak struktur gigi secara umum yang terjadi pada saat itu. menyebabkan karies.
Karies yang ada di masa sekarang ternyata sudah ada dari masa lalu yang terjadi akibat pola kehidupan manusia yang kurang menjaga kesehatan gigi dan mulut. Pola diet dan jenis makanan yang dikonsumsi ST1 pada masa hidupnya belum bisa dibuktikan hanya dari satu jenis patologi saja. Oleh karena itu, penelitian lebih lanjut mengenai patologi pada individu ST1 maupun individuindividu lainnya di kawasan Gunung Sewu sangat diperlukan untuk mengetahui pola diet atau jenis makanan yang dikonsumsi manusia masa Holosen Awal yang kemudian dapat dikaitkan dengan aktivitas dan budaya yang

\section{DAFTAR PUSTAKA}

Amano, N., Rivals, F., Moigne, AM., Ingico, T., Semah, F., dan Simanjuntak, T. 2016. Paleoenvironment in East Java During The Last 25,000 Years as Inferred From Bovid and Cervid Dental Wear Analyses. Journal of Archaeological Science: Reports $10: 155-165$.

Arizona, F. 2016. Patologi Gigi-Geligi Pada Tengkorak Manusia Liang Bua, Manggarai, Flores, Nusa Tenggara Timur. Antrounairdotnet, 2 (2) : 258 - 267.

Détroit, F. 2002. Origine et évolution des Homo sapiens en Asie du Sud-Est: Descriptions et analyses morphométrique de nouveaux fossils". Thése du Docteural du MNHN. Paris.

Hameau, S., C. Falguères, J.J. Bahain, F. Sémah, A.M. Sémah, dan J.M. Dolo. 2007. ESR dating in Song Terus cave (East Java, Indonesia). Quaternary Geochronology, 2 : 398-402.

Hillson, S. 2005. Teeth Second Edition. Cambridge University Press. UK.

Hublin, J., dan Bailey S. E. 2007. Dental Perspectives on Human Evolution : State of the Art Research in Dental Paleoanthropology. Published by Springer.

Humphrey, L.T., De Groote, I., Morales, J., Barton, N., Collcutt, S., dan Bouzouggar, A. 2014. Earliest evidence for caries and exploitation of starchy plant foods in Pleistocene hunter-gatherers from Morocco. PNAS, 3 (111) : 954 - 959.

Larsen, C.S ., Shavit, R., dan Griffin, M.C. 1991. Dental Caries Evidence for Dietary Change $\therefore$ An Archaeological Context. Wiley-Liss Inc.

Moynihan, P. J. 2005. The Role and Diet Nutrition in The Etiology and Prevention of Oral Disease. Bulletin of World Health Organization, 83 (9) : 694 - 699. 
Noerwidi, S. 2012. The significance of the Holocene human skeleton Song Keplek 5 in the history of human colonization of Java: a comprehensive morphological and morphometric study. Thesis Master Erasmus Mundus en Quaternaire et Préhistoire.

Ortner, D. J. 2003. Identification of Pathological Conditions in Human Skeletal Remains. Academic Press, San Diego.

Perelli, F. 2010. Comparative Morphometric Analysis of the Long Limb Bones of the Holocene Human skeletons Song Keplek 4 and Song Terus K9 (East Java, Indonesia). University' Degli Studi Di Ferrara, Italy.

Ramayanti, S., dan Purnakarya, I. 2013. Peran Makanan Terhadap Kejadian Karies Gigi. Jumal Kesehatan Masyarakat, 7 (2) : 89 - 93.

Sémah, François., Anne-Marie Sémah., C. Falguères., F. Détroit., Xavier Gallet, S. Hameau., Anne-Marie Moigne., dan Simanjuntak H.T. 2004. The significance of the Punung karstic area (eastern Java) for the chronology of the Javanese Paleolithic, with special reference to the Song Terus cave. Modern Quaternary Research Southeast Asia, $18: 45-62$.

Simanjuntak, T. 2004. New Insight of The Prehistoric Chronology of Gunung Sewu, Java, Indonesia. Modern Quaternary Research in Southeast Asia: Quaternary Research, $18: 9-30$.

Tampubolon, N. S. 2005. Dampak Karies Gigi dan Penyakit Periodontal Terhadap Kualitas Hidup. Pidato Pengukuhan. USU Repository, Medan.

Tiauzon, Archie. 2011. Lithic Technology In Song Terus During The Late Middle Pleistocene and The Early Upper Pleistocene. Master Erasmus Mundus en Quartenaire et Prehistory.

White, T. D, dan Folkens P.A. 2005. The Human Bone Manual. Elsevier Academic Press, London.

Widianto, Harry. 2002. "Prehistoric Inhabitants in Gunungsewu", dalam Truman Simanjuntak ed., Gunungsewu in Prehistoric Times, Gadjah Mada University Press, Yogyakarta: 227-248.

Widianto H, dan Noerwidi, S. 2010. Atlas Prasejarah Indonesia. PT Kharisma Ilmu. 